\title{
Technical Possibilities of Biogas Production from Olive and Date Waste in Jordan
}

\author{
Mohammad Al-Addous, ${ }^{\text {a }}$ Mohammad Alnaief, ${ }^{\text {, } *}$ Christina Class, ${ }^{\mathrm{c}}$ Abdullah Nsair, ${ }^{\mathrm{d}}$ \\ Kerstin Kuchta, ${ }^{\mathrm{d}}$ and Malek Alkasrawi ${ }^{\mathrm{e}}$ \\ Using renewable energy sources provides a promising solution to \\ minimize the overuse of conventional energy sources as well as to reduce \\ pollution. Biogas technology is one solution that offers the conversion of \\ waste streams to a renewable source of higher value. Anaerobic digestion \\ of organic waste from industrial processes produces energy in the form of \\ biogas, which has an advantage of preventing odor release, and has \\ minimal pathogens. In this study, two different sources of bio-waste were \\ investigated for their biogas potential, namely palm date waste and olive \\ pomace. All of the samples produced biogas; however, the amount \\ produced was only $20 \%$ to $40 \%$ of what conventional substrates typically \\ produced. Producing biogas that uses only olive biomass offers a solution \\ to the waste disposal problem, but it is not efficient for biogas production. \\ For optimal heat utilization and maximizing biogas production, mixing of \\ different feedstock was identified as a valid solution. Hence, a model of \\ mixing other sources of bio-waste, such as chicken manure, can activate \\ sludge and is proposed to boost the biogas production.
}

Keywords: Biogas potential; Olive pomace; Renewable energy; GB21 Test

Contact information: a: Department of Energy Engineering, School of Natural Resources Engineering Management, German Jordanian University, Amman Madaba Street, P.O. Box 35247, Amman 11180 Jordan; b: Pharmaceutical and Chemical Engineering Department, School of Applied Medical Sciences, German Jordanian University, Amman Madaba Street, P.O. Box 35247, Amman 11180 Jordan; c: Department of Basic Sciences, Ernst-Abbe-Hochschule Jena, Germany; d: Institute of Environmental Technology and Energy Economics, Hamburg University of Technology, Harburger Schloßstr 36, 21079 Hamburg - Germany; e: Waste Resource Management Department of Chemical Engineering, University of Wisconsin, Stevens Point, USA; *Corresponding author: Mohammad.alnaief@gju.edu.jo

\section{INTRODUCTION}

The Hashemite Kingdom of Jordan is located in the centre of the Middle East with a total area of $88,778 \mathrm{~km}^{2}$ (DOS 2015a). Due to recent instability and revolutions in the Arab region, Jordan hosts many refugees and as a result the population has rapidly increased. The 2015 census assessed a population increase of more than 9.5 million, while it was only about 7 million in 2011. Approximately $30 \%$ of the population is not Jordanian and are refugees, immigrants, or employees mainly from neighbouring countries (DOS 2015c). This unplanned rise in the population puts a tremendous pressure on the social and energy demands, which require novel solutions from the Jordanian government. Using renewable energy sources is a promising solution to cope with the increasing energy demands.

Because Jordan is short on fuels, it has had to depend on importing energy resources regardless of their type, which was approximately $97 \%$ of the total primary energy needed in 2015 (MEMR 2015). The Jordanian government strategy during the years 2015 to 2018 
is to reduce the dependence on imported fossil fuels and other types of energy resources. This goal will be achieved by increasing the share of renewable energies from $2 \%$ in 2015 to $8 \%$ in the total energy mix by the year 2018 (MEMR 2015). Next to solar radiation and wind, biogas is considered to be one of the most promising renewable energy sources for Jordan that is not affected by time, weather conditions, or the location (Budzianowski 2016; Sárvári Horváth et al. 2016).

Municipal solid waste contains approximately 50\% of organic-origin waste (Sweepnet 2014), and until now this waste has hardly been used as a resource in Jordan. According to a report in $2014,48 \%$ of the total waste was landfilled, $45 \%$ was openly disposed, and the remaining 7\% was recycled (Sweepnet 2014). In contrast, the amount of agricultural waste was more than 4 million tons per year. Landfills can lead to ecological problems due to leakage and gas emissions. Aljaradin and Persson (2012) proposed that anaerobic digestion was an environment-friendly solution to treat organic waste in Jordan.

The production of biogas through anaerobic digestion (AD) is considered as an environmentally friendly process utilizing organic waste produced as a by-product of the agricultural and farming industries (Appels et al. 2011). Moreover, it can help tackle the problem of the organic waste fraction of municipalities' waste and food industries' waste (Yadvika et al. 2004; Lorenz et al. 2013). The main product is a renewable energy source called biogas, and the by-product is a digestate that can be processed further to produce bio-fertilizers (Amon et al. 2007; Lukehurst et al. 2010). In theory, all kinds of bio-waste can be used as a feedstock for the AD plants. However, the loading process should be carefully planned to allow the chain of bio-degradation by the anaerobic bacteria to yield the biogas at the end of the process (Rajagopal et al. 2013; Yuan and Zhu 2016). The degradation process is the result of the collaboration between different groups of bacteria in a way that each group forms the substrate of another group. Efficient processes can be achieved if the rate of each degradation process is balanced (Yong et al. 2015).

Due to the economical, environmental, and social benefits of bioenergy, biogas industries have been established across many European Union countries including Germany, Denmark, Austria, Sweden, Netherlands, France, Spain, Italy, United Kingdom, and Belgium. Other countries are still in the developing stage or evaluating these technologies (Sophie 2008; Budzianowski 2016; Sárvári Horváth et al. 2016). Approximately $80 \%$ of Jordan is considered arid (Hadadin et al. 2010). One of the major challenges Jordan faces is the water supply of its population. Therefore, it is important that the production of biogas is solely based on agricultural and organic waste. The use of specific plants, like Jatropha (Jatropha integerrima), solely planted for the production of energy cannot be considered as a viable approach.

Recently, several studies have considered the potential of using biogas production in Jordan. Previous reports discussed the use of organic waste and manure (Abu-Ashour et al. 2010; Momani and Shawaqfah 2013; Al-Hamamre et al. 2014). In addition, biogas production from olive mill was reported as being a promising method to reduce the impact of olive oil industry effluent on the environment. Tekin and Dagic (2000) studied the biogas production from olive pomace and used a $1 \mathrm{~L}$ anaerobic digester. The concentration of olive pomace was mixed with water to achieve 5,10 , and $15 \mathrm{wt} \%$. The biogas yield was 0.028 to $0.09 \mathrm{~g}^{-1} \mathrm{TS}$ added. Alagöz et al. (2015) investigated the effect of microwave and ultrasonic pretreatment on anaerobic digestion of olive pomace and wastewater sludge; 180 $\mathrm{mL}$ of $\mathrm{CH}_{4} \mathrm{~g}^{-1} \mathrm{VS}$ was reported for olive pomace without treatment, while a $24 \%$ to $52 \%$ increase of biomethane production was reported after treatment (Aylin Alagöz et al. 2015). Gunay and Karadag reviewed different approaches for anaerobic digestion of olive mill 
effluent. Different technologies and various pretreatment methods were compared for their effect on the digestion process. A co-digestion process with a pretreatment of the olive effluent was recommended to improve the biomethane production (Gunay and Karadag 2015)

In this work, two important agricultural products, olive and date waste, were used for the evaluation of biogas production. To boost the biogas production of the used substrates, several mixing criteria were proposed.

\section{Olives and Dates in Jordan's Agriculture}

Olive trees are one of the most planted trees in Jordan and cover approximately $36 \%$ of the cultivated area (Bassam 2015). In the last five years, Jordan produced approximately $1.4 \%$ of the global production of table olives. A large percentage of this product is used for olive oil (IOC 2016). Olive oil production reached approximately $0.9 \%$ of olive oil's production worldwide (IOC 2016). As a by-product of this process, a large amount of olive pomace is generated. Currently, there is no clear process to eliminate this amount of waste, besides ambient drying and incineration for household heating. However, this solution is limited due to the health and environmental problems associated with the burning process, and the low heating values of the pomace. One promising solution of this problem is the anaerobic digestion of the pomace to produce biogas and a quality digestate as a bio-fertilizer (Tekin and Dalgıç 2000).

Another possible waste that can be utilized is from date and palm trees. In 2015 , approximately 27,000 acres were planted with 477,800 palm trees. The annual date production in 2015 amounted to approximately 20,140 tons of dates (DOS 2015b). Thus, it is possible to utilize the waste produced from this growing sector, and it can be used as a part of other agricultural wastes. In this work, the characteristics of dates and olive waste, including their leaves, are presented and the possibilities to produce biogas from these substrates are discussed.

\section{EXPERIMENTAL}

To determine the biogas potential of dates and olive waste, the total solids, volatile solids, and calorific values were determined using standard procedures. The total solids (TS) and the volatile solids (VS) values were important factors to be determined prior to a biogas potential test to fix the ratio of substrate to inoculum. Generally, the value should be less than 0.5 Otherwise an unbalanced chain reaction may occur and result in the elimination of the methanogenesis step (VDI 4630 2006; Yuan and Zhu 2016). The biogas production under standard conditions was equally measured using an Eudiometer system, and the methane content was measured.

\section{Materials}

The inoculum for biogas potential tests was taken as thickened-digested sludge from the municipal wastewater treatment plant in Hamburg, Germany and incubated at 35 ${ }^{\circ} \mathrm{C}$ for $5 \mathrm{~d}$ before the start of the experiment. The incubation step was necessary to reduce the gas production in the sludge. Sodium chloride $(\mathrm{NaCl})$, citric acid, and crystalline cellulose were acquired from Sigma Aldrich (Saint Louis, USA). All chemicals were used without further purification. 


\section{Sample selection}

Representative olive oil industry pomace and pressed olive samples were collected from three different olive mills located in the north and the west of Jordan. The olive waste samples from Aldajani (Ajloun) and Hofa (Al-Wasateyeh) olive mills were air-dried in the sunshine, while the sample from the Alsa'adi mill olive pomace was freshly pressed and not yet dried. The green olive leaves were brought from Al-Wasateyeh, Jordan. Representative samples of palm leaves (green and dry) were collected from Al- Karameh, Jordan Valley.

\section{Methods}

Total solids

According to the German standard DIN 38414 (1985), for each sample, three dried crucibles were heated to $105{ }^{\circ} \mathrm{C} \pm 2{ }^{\circ} \mathrm{C}$ for $1 \mathrm{~h}$ and left to cool down in a desiccator to the ambient temperature. Next, their weight was recorded. Then, the crucibles were filled with a certain amount of the samples and placed in an oven at $105{ }^{\circ} \mathrm{C}$ for $24 \mathrm{~h}$. Finally, the crucibles were placed in the desiccator and left to cool down to the ambient temperature and their weight was recorded.

\section{Volatile solids}

According to the German standard DIN 38409 (1987), the dried sample from the TS measurement was ground to a particle size of $<0.25 \mathrm{~mm}$. The particles were then filled in ceramic crucibles, weighed, and placed in a furnace. The heating program consisted of $20 \mathrm{~min}$ at $200{ }^{\circ} \mathrm{C}, 30 \mathrm{~min}$ at $300{ }^{\circ} \mathrm{C}$, and finally $5 \mathrm{~h}$ at $550{ }^{\circ} \mathrm{C}$ with a heating rate of 10 ${ }^{\circ} \mathrm{C} / \mathrm{min}$. Then, the heated sample was placed in a desiccator and left to cool to the ambient temperature. Finally, the weight of the remaining ash was recorded.

\section{Calorific value}

The calorific values of the biomass were measured according to the German standard DIN 51900 (2005), using an IKA C 5000 pump calorimeter (IKA ${ }^{\circledR}$-Werke, Staufen, Germany).

\section{Anaerobic digestion and biogas formation potential}

Anaerobic digestion tests were conducted in triplicate, following the recommendations of the Association of German Engineers Standards (VDI 4630 2006).

To estimate the biogas potential production from the samples, the Eudiometer system was used. It was composed of 500-mL reactors, each one connected to a Eudiometer tube, which had been previously filled with a barrier solution that consisted of $200 \mathrm{~g}$ of $\mathrm{NaCl} / \mathrm{L}$ and $5 \mathrm{~g} / \mathrm{L}$ of citric acid. The biogas produced in each reactor was released in the tube so that the volume could be measured daily via solution displacement. The biogas volume was calculated under ambient conditions of the climate room at $310 \mathrm{~K}$ and $1 \mathrm{bar}$. The samples of produced biogas were analyzed using a GC-TCD model HP 6890 (HewlettPackard, USA), which allowed for the detection of methane and carbon dioxide. A reference set was investigated for their biogas production. The results were discarded when the results were not comparable to the standard value.

\section{Theoretical biogas potential}

The theoretical biogas calculation was based on the feedstock availability and was performed according to several mathematical models to predict the biogas potential. 
Hashimoto et al. (1981) and Tarvin and Buswell (1934) developed rigorous calculation methods of biogas production using various organic feedstock (Tarvin and Buswell 1934; Hashimoto et al. 1981). The two methods were equally reviewed and verified in comparison with other calculation methods (Nielfa et al. 2015).

The equation for methane potential was first introduced by Tarvin and Buswell (1934). The model is very effective and used in several studies (Nielfa et al. 2015). Equation 1 represents the theoretical production rate for any substrate:

$$
B M P_{\text {thCOD }}=\frac{n_{C H_{4} R T}}{p V S S_{\text {added }}}
$$

The total number of methane moles can be calculated using Eq. 2, once the chemical oxygen demand (COD) was obtained,

$$
n_{\mathrm{CH}_{4}}=\frac{C O D}{64(\mathrm{~g} / \mathrm{mol})}
$$

where $\left(B M P_{\text {thCOD }}\right), \mathrm{R}, \mathrm{T}, \mathrm{pVSS}$, and $n \mathrm{CH}_{4}$ represent the gas constant, ambient temperature $(\mathrm{K})$, the volatile solids (g), and methane moles (mole), respectively. Both Eqs. 1 and 2 are described by Nielfa et al. (2015).

\section{RESULTS AND DISCUSSION}

\section{Basic Characterization}

Table 1 shows the results of the tests for all 6 samples. As expected, the fresh leaves had lower total solids and organic dry matter than the dried leaves. The values of both types of leaves were comparable. The highest values were expected from the olive pomace. The olive pomace was made of residues from olive oil production, i.e. the fruit and kernel after the olives were pressed. The value of the Alsa'adi's olive pomace was much lower than that of Aldajani's and Hofa's olive pomace due to the higher level of water received during the raining season and lower than average temperature compared with other locations of sampling.

Table 1. Characterization of the Investigated Substrates for their Dry Matter, Volatile Matter, and Calorific Value

\begin{tabular}{|c|c|c|c|}
\hline \multirow{2}{*}{ Sample } & $\begin{array}{c}\text { Total Solids } \\
\text { (TS) }\end{array}$ & $\begin{array}{c}\text { Organic Dry Matter } \\
\text { (VS) }\end{array}$ & $\begin{array}{c}\text { Calorific } \\
\text { Value }\end{array}$ \\
\cline { 2 - 4 } & $\mathrm{kg} \mathrm{kgFM}^{-1}$ & $\mathrm{~kg} \mathrm{kgFM}^{-1}$ & $\mathrm{~kJ} \mathrm{kgFM}^{-1}$ \\
\hline Olive Leaves & 0.48 & 0.42 & 8917 \\
\hline Green Palm Leaves & 0.46 & 0.44 & 8706 \\
\hline Dry Palm Leaves & 0.77 & 0.69 & 14109 \\
\hline $\begin{array}{c}\text { Aldajani Olive Mill Olive } \\
\text { Pomace }\end{array}$ & 0.90 & 0.86 & 19170 \\
\hline $\begin{array}{c}\text { Alsa'adi Olive Mill Olive } \\
\text { Pomace }\end{array}$ & 0.57 & 0.55 & 11190 \\
\hline Hofa Olive Mill Olive Pomace & 0.90 & 0.88 & 19710 \\
\hline
\end{tabular}


The calorific values of the 6 samples had similar proportions. The fresh leaves had the lowest values, while the olive pomace had the highest value. The same behavior in Alsa'adi olive pomace was observed with a much lower calorific value than the other two olive pomaces and dry palm leaves.

\section{Biogas Formation Potential Test}

After the basic characterization of the total solids, volatile solids, and the calorific values for the samples, the gas formation potential test (GB21) was performed to investigate the sample potential for the production of biogas. As shown in Table 2, the biogas potential (BGP) of the samples fell in the range of $92 \mathrm{Nl} \cdot \mathrm{Kg}_{\mathrm{FM}}{ }^{-1}$ to $147 \mathrm{Nl} \cdot \mathrm{Kg}_{\mathrm{FM}}{ }^{-1}$. The lowest value was observed in the Alsa'adi Olive Mill olive pomace, while the highest was observed in Hofa Olive Mill olive pomace. Moreover, the average BGP from the green palm leaves and the dry palm leaves were higher than olive leaves or olive pomace. However, the TS, VS, and calorific values for the pomaces of Aldajani Olive Mill and Hofa Olive Mill were similar; the biogas and methane potentials showed a noticeable difference. Considerably lower values of Alsa'adi Olive Mill olive pomace were observed.

Table 2. Characterization of the Investigated Substrates for their Biogas Formation Potential and Methane Potential

\begin{tabular}{|c|c|c|}
\hline \multirow{2}{*}{ Sample } & $\begin{array}{c}\text { Biogas Formation } \\
\text { Potential }\end{array}$ & Methane Potential \\
\cline { 2 - 3 } & NL kgFM $^{-1}$ & $L_{\text {Methane } \mathrm{kgFM}^{-1}}$ \\
\hline Olive Leaves & 107 & 71.29 \\
\hline Green Palm Leaves & 142 & 94.75 \\
\hline Dry Palm Leaves & 132 & 90.46 \\
\hline Aldajani Olive Mill Olive Pomace & 125 & 90.18 \\
\hline Alsa'adi Olive Mill Olive Pomace & 92 & 64.97 \\
\hline Hofa Olive Mill Olive Pomace & 147 & 103.81 \\
\hline
\end{tabular}




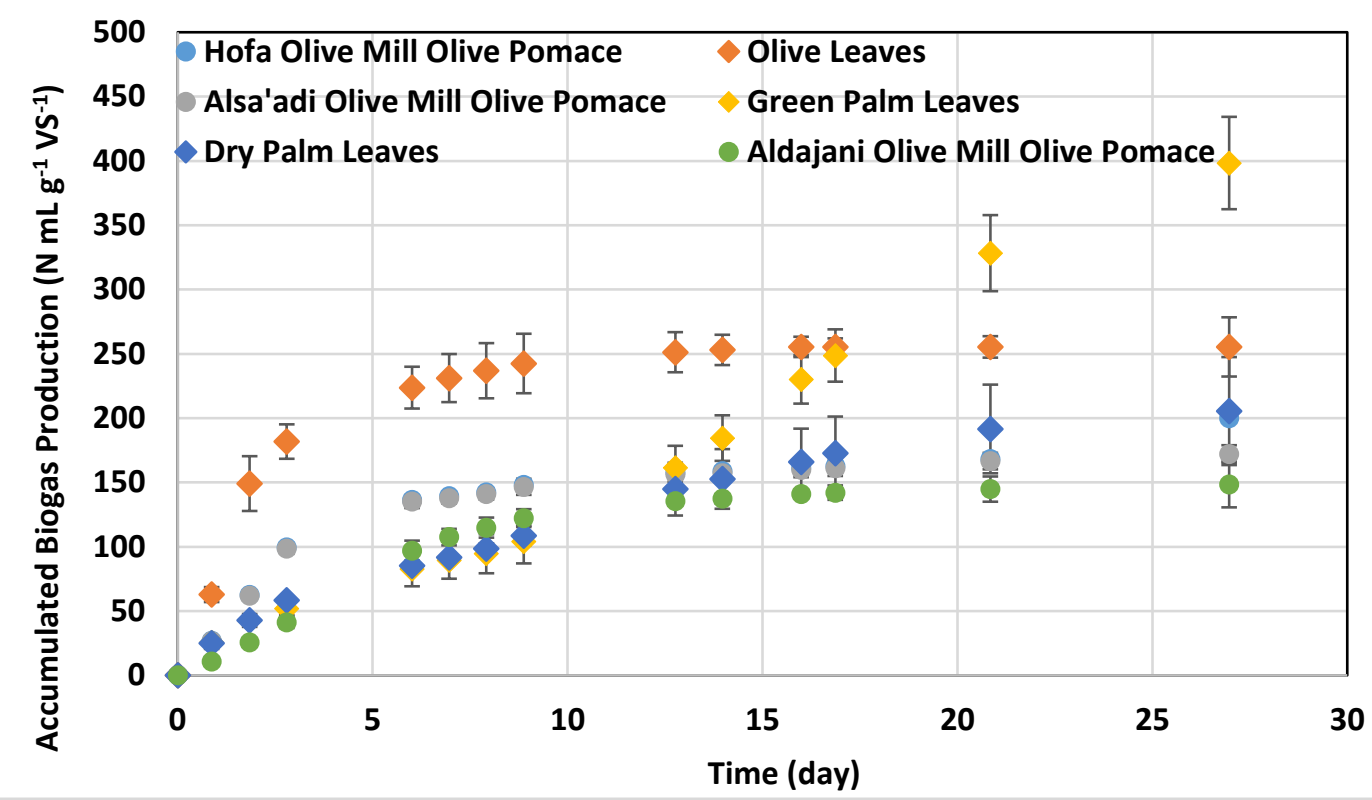

Fig. 1. Accumulative biogas production of the substrates using GB21 climate room method

Figure 1 shows the cumulative biogas production of the tested samples over $27 \mathrm{~d}$. Most samples reached a plateau after $15 \mathrm{~d}$. The only sample that deviated from this behavior was the green palm leaves. Furthermore, the olive leaf samples produced the majority of the biogas within $7 \mathrm{~d}$ of the start of the experiment. In addition, the samples from Alsa'adi Olive Mill and Hofa Olive Mill showed similar behavior in this test, which was comparable to that of the Aldajani Olive Mill olive pomace. In contrast, the behavior of the dry and green palm leaves were different.

Usually, biogas plants are design to use energy crops such as sugar beet, fodder beet, corn, and serials such as triticale and wheat. The biogas production from such crops range between 420 to $800 \mathrm{~N} \mathrm{ml} \cdot \mathrm{g}^{-1} \mathrm{VS}^{-1}$ (Carlini et al. 2015; Esposito et al. 2012; MaciasCorral et al. 2008; Weiland 2003, 2010). Comparing the results presented in this article to those available in the literature, shows that the yield of biogas smaller. However, the biogas technology can offer an environmental solution to the olive oil industries. Further, codigestion with other organic substrate can boost the biogas yield.

Table 3 shows the results of the gas chromatographic (GC) analysis for the produced biogas for the tested samples. The main compositions of the analyzed biogas were methane, carbon dioxide, and some traces of oxygen. The methane percentages in all of the biogases produced ranged from approximately $66.6 \%$ to $72.4 \%$. The lowest value was recorded for the olive leaves, while the largest was for the Aldajani olive pomace. Moreover, the percentages of carbon dioxide in all produced biogas ranged between $25.8 \%$ and $32.5 \%$. The lowest value observed was for the sample from Aldajani olive pomace, and the largest was for the green palm leaves. Finally, the largest bio-methane production was for the Hofa olive pomace and the smallest was for the Alsa'adi olive pomace (Table $1)$. 
Table 3. Biogas Compositional Analysis of Different Substrate Used

\begin{tabular}{|c|c|c|c|}
\hline Sample & $\mathrm{CH}_{4}(\%)$ & $\mathrm{O}_{2}(\%)$ & $\mathrm{CO}_{2}(\%)$ \\
\hline Olive Leaves & $66.44 \pm 3.21$ & $1.32 \pm 0.04$ & $32.24 \pm 1.54$ \\
\hline Green Palm Leaves & $66.65 \pm 3.30$ & $0.85 \pm 0.07$ & $32.50 \pm 1.62$ \\
\hline Dry Palm Leaves & $68.64 \pm 3.45$ & $1.07 \pm 0.05$ & $30.29 \pm 1.52$ \\
\hline Aldajani Olive Pomace & $72.37 \pm 3.25$ & $1.80 \pm 0.07$ & $25.83 \pm 1.41$ \\
\hline Alsa'adi Olive Pomace & $70.85 \pm 3.55$ & $1.35 \pm 0.03$ & $27.80 \pm 1.27$ \\
\hline Hofa Olive Pomace & $70.67 \pm 3.41$ & $1.81 \pm 0.1$ & $27.52 \pm 1.05$ \\
\hline
\end{tabular}

\section{Simulation of Feedstock Mixing Options}

The measured biogas yield in this study was relatively low (Table 2) and it tackles the problem of waste management and disposal. The low biogas yield resulted from low phosphorus levels in the substrates, which is a basic element for the methanogenic optimal growth (Marques 2001; Macias-Corral et al. 2008; Fantozzi and Buratti 2009) However, the yield can be improved by mixing the cellulosic materials with other substrates (MaciasCorral et al. 2008). Feedstock mixing would provide additional nutrients, supplements, phosphorus, other minerals, and a balance of the feedstock with the $\mathrm{C}: \mathrm{N}$ ratio to maximize the biogas production (Fantozzi and Buratti 2009). When the ratio of C:N increased, it resulted in a rapid consumption of nitrogen before the carbon was metabolized. As an illustrative example, Wu et al. (2010) found that $\mathrm{C}: \mathrm{N}$ ratio of 20:1 was favorable for codigestion of oat straw and wheat straw. In contrast, if the ratio of $\mathrm{N}: \mathrm{C}$ was high it led to the accumulation of high concentrations of ammonium, which is toxic to the environment and hostile to the methanogens bacteria. The current $\mathrm{C}: \mathrm{N}$ ratio of 50:1 explained that the low biogas yield was most likely attributable to the quick depletion of $\mathrm{N}$ (Wu et al. 2010). Fantozzi and Buratti (2009) found that mixing olive husk and inoculum (rumen fluid) increase the methane yield by ten fold in comparison to when live husk was used alone. This is an interesting finding and supports the assumption that olive paste requires additional feedstock mixing to maximize the biogas yield (Fantozzi and Buratti 2009). Mixing feedstock includes the local waste available in abundance, but unveils a management burden. The potential mixing feedstock includes animal manure, agriculture waste, and waste from slaughtering houses. Previous studies showed that various feedstock mixing improve significantly the biogas yield (Marques 2001; Macias-Corral et al. 2008; Fantozzi and Buratti 2009; Wu et al. 2010). The mixing feedstock would provide essential elements and a balance of carbon, phosphorus, and nitrogen (C:P:N). Mathematical modeling and process simulation offers practical tools for biogas prediction. One of the earliest models developed was the Hashimoto equation and was used efficiently to predict the biomethane from various feedstock (Hashimoto et al. 1981). However, the chemical oxygen demand (COD) content was utilized to predict the methane potentials in Eq. 1. Macias-Corral (2008) showed that the co-digestion of municipal solid waste and cow manure provides synergistic effect which tackles the imbalance of the nutrients and boosts the methane yield.

A spreadsheet that utilized the mathematical modeling was developed to simulate the addition of wastewater sludge (WS: $5 \%$ dry matter) and chicken manure (CM) at 
various maxing ratios with olive waste. The WS and CM was chosen because it is available abundantly in Jordan. It shows that mixing animal manure and olive waste would boost the biogas yield at a higher rate. Replacing the animal manure with household waste would not boost the yield due to its low nitrogen content. The mixing of feedstock was found to be an attractive process option to enhance the yield production of biogas. The mixing modification subsequently would improve the process economy remarkably and provide an economical tool for waste management combined with power generation from a biogas facility.

The following process was used to estimate the baseline for a successful production theme. The process will be based on processing 10,000 tons of olive past (OP) annually with several configurations. Because the olive waste provided low biogas yield due to an unbalanced ratio of $\mathrm{C}: \mathrm{N}$, several mixing scenarios were used with other waste to balance the $\mathrm{C}: \mathrm{N}$ ratio and provide an additional source of phosphorus. Marques (2001) showed that the organic matter which, in association to its high $\mathrm{C} / \mathrm{N}$ ratio and low $\mathrm{pH}$, enhance the biological degradation processes. Table 4 shows several mixing scenarios with potential biogas production with the main feed kept constant at 10,000 tons. The biogas potential production from mixed feedstock was based on theoretical calculations using Eqs. 1 and 2, and an online model was developed by BiogasWorld. The olive waste was mixed with wastewater sludge (WS: 5\% dry matter), chicken manure (CM), and at various mixing ratios. The WS and CM were selected due to their abundance in Jordan. These wastes are generally hard to manage and dispose. The first scenario (S1) presented the base case where only olive past (OP) was used in the proposed biogas plant. The second scenario (S2), had a ratio of 10:5:1 of OP:WS:CM, respectively. The third scenario (S3), had a ratio of 10:10:1 for OP:WS:CM, respectively. The fourth scenario (S4), mixed OP and CM and had a 1:1 ratio. A similar finding was obtained by Marques 2001 by finding that addition of piggery effluent enhanced to higher degree the anaerobic digestion of olive mill (Marques 2001). The aim of biogas usage is for combined heat and power (CHP) to the local farm community. The simulation was based on the solid content before digestion at $30 \%$ TS where the solid content should be adjusted for the digester type. Mixing the feedstock boosted the biogas production by several fold. This was due to the balanced ratio of C:N by other feedstock added to OP. A considerable amount of GHG reduction was achieved in the overall process. However, the mixing was tuned and optimized to maximize the overall biogas yield. The best obtained scenario, when the OP was mixed equally with CM, provided over 1.4 million $\mathrm{m}^{3}$ of biogas, which is equivalent to about 28 million $\mathrm{kWh}$ of electricity. Altering the process configuration, for example biogas production in multistage reactor might offer another possibility of improving the overall yield of the process (Krishnan et al. 2016). 
Table 4. Simulation Results of Several Feedstock Mixing Scenarios for Optimal Biogas Production

\begin{tabular}{|c|c|c|c|c|}
\hline \multirow{2}{*}{} & \multicolumn{4}{|c|}{ Process Scenarios } \\
\cline { 2 - 5 } & $\mathrm{S} 1$ & $\mathrm{~S} 2$ & $\mathrm{~S} 3$ & $\mathrm{~S} 4$ \\
\hline $\begin{array}{c}\text { Dry Matter } \\
\mathrm{EL}(\mathrm{kWh})\end{array}$ & 254,040 & $2,584,200$ & $2,715,600$ & $2,847,000$ \\
\hline (m³/year) & 850,000 & $1,310,050$ & $1,380,238$ & $1,442,813$ \\
\hline Mixing Ratio & $1: 0: 0$ & $10: 5: 1$ & $10: 10: 1$ & $1: 1$ \\
\hline Feedstock & OP & OP:WS:CM & OP:WS:CM & OP:CM \\
\hline $\begin{array}{c}\text { Methane Potential } \\
\begin{array}{c}\text { GHG Reduction } \\
\text { (tons } \mathrm{CO}_{2} \text { eq. } \text { yr }^{-1} \text { ) }\end{array}\end{array}$ & 55 & 557 & 587 & 614 \\
\hline
\end{tabular}

\section{CONCLUSIONS}

1. Olive pomace and date palm leaves were successfully investigated using a GB21 test for evaluating the potential of biogas formation.

2. The biogas composition was mainly methane and carbon dioxide.

3. The maximum methane production was obtained for the Hofa Olive mill's olive pomace with a value of $103 \mathrm{NL} \cdot \mathrm{Kg}_{\mathrm{FM}}{ }^{-1}$.

4. Although the value was smaller than energy crops or animal manure, the process should still be considered for environmental reasons. Moreover, possible valorization of the process can be achieved by processing the digestate to a bio fertilizer.

5. Olive pomace could be utilized for biogas production if it was mixed with other organic waste to supply crucial nutrients for methanogenesis.

\section{ACKNOWLEDGMENTS}

The described work is part of a project called "Biogas Production in Local Communities in Jordan" and was funded by the European Union and the Ministry of Energy and Mineral Resources of the Hashemite Kingdom of Jordan). The authors are thankful for the seed grant fund provided by the deanship of graduate studies and research at GJU.

\section{REFERENCES CITED}

Abu-Ashour, J., Qdais, H. A., and Al-Widyan, M. (2010). "Estimation of animal and olive solid wastes in Jordan and their potential as a supplementary energy source: An overview," Renewable and Sustainable Energy Reviews 14(8), 2227-2231. DOI: 10.1016/j.rser.2010.03.001

Aljaradin, M., and Persson, K. M. (2012). "Comparison of different waste management technologies and climate change effect- Jordan," American Journal of Climate Change 1(2), 57-63. DOI: 10.4236/ajcc.2012.12006 
Al-Hamamre, Z., Al-Mater, A., Sweis, F., and Rawajfeh, K. (2014). "Assessment of the status and outlook of biomass energy in Jordan," Energy Conversion and Management 77, 183-192. DOI: 10.1016/j.enconman.2013.09.041

Amon, T., Amon, B., Kryvoruchko, V., Machmüller, A., Hopfner-Sixt, K., Bodiroza, V., Hrbek, R., Friedel, J., Pötsch, E., Wagentristl, H., Schreiner, M., and Zollitsch, W. (2007). "Methane production through anaerobic digestion of various energy crops grown in sustainable crop rotations," Bioresource Technology 98(17), 3204-3212. DOI: 10.1016/j.biortech.2006.07.007

Appels, L., Lauwers, J., Degrève, J., Helsen, L., Lievens, B., Willems, K., Van Impe, J., and Dewil, R. (2011). "Anaerobic digestion in global bio-energy production: Potential and research challenges," Renewable and Sustainable Energy Reviews, 15(9), 4295-4301. DOI: 10.1016/j.rser.2011.07.121

Aylin Alagöz, B., Yenigün, O., and Erdinçler, A. (2015). "Enhancement of anaerobic digestion efficiency of wastewater sludge and olive waste: Synergistic effect of codigestion and ultrasonic/microwave sludge pre-treatment," Waste Management 46(Supplement C), 182-188. DOI: 10.1016/j.wasman.2015.08.020

Bassam Al-Qarallah. (2015). "Potential use of olive pellets in heating tomato green houses. Case A: Jordan Valley," World Journal of Agricultural Sciences 11(2), $107-$ 111. DOI: 10.5829/idosi.wjas.2015.11.2.1851

Budzianowski, W. M. (2016). "A review of potential innovations for production, conditioning and utilization of biogas with multiple-criteria assessment," Renewable and Sustainable Energy Reviews 54, 1148-1171. DOI: 10.1016/j.rser.2015.10.054

Carlini, M., Castellucci, S., and Moneti, M. (2015). "Anaerobic co-digestion of olive-mill solid waste with cattle manure and cattle slurry: Analysis of bio-methane potential," Energy Procedia 81, 354-367. DOI: 10.1016/j.egypro.2015.12.105

DIN 38409. (1987). "Glührückstand (volitile content)," in: German standard methods for the examination of water, waste water and sludge; parameters characterizing effects and substances (group $H$ ); determination of total dry residue, filtrate dry residue and residue on ignition, Beuth Verlag $\mathrm{GmbH}$, Berlin.

DIN 38414. (1985). "Trockenrückstand (dry matter content)," in: German standard methods for the examination of water, waste water and sludge; sludge and sediments (group S); determination of water content, of dry residue and of solids content (S 2), Beuth Verlag GmbH, Berlin, 1-5, 7.

DIN 51900. (2005). "Calorific value," in: Testing of solid and liquid fuels Determination of gross calorific value by the bomb calorimeter and calculation of net calorific value - Part 3: Method using adiabatic jacket, Beuth Verlag GmbH, Berlin.

DOS. (2015a). Area and Topography, Department of Statistics, Jordan, 2.

DOS. (2015b). Planted Trees in Jordan 2015, statistics, DOS, Jordan, 1.

DOS. (2015c). Population and Housing Sensus, Department of Statistics, Jordan, 70.

Esposito, G., Frunzo, L., Liotta, F., Panico, A., and Pirozzi, F. (2012). "Bio-methane potential tests to measure the biogas production from the digestion and co-digestion of complex organic substrates," The Open Environmental Engineering Journal 5(1).

Fantozzi, F., and Buratti, C. (2009). "Biogas production from different substrates in an experimental continuously stirred tank reactor anaerobic digester," Bioresource Technology 100(23), 5783-5789. DOI: 10.1016/j.biortech.2009.06.013

Gunay, A., and Karadag, D. (2015). "Recent developments in the anaerobic digestion of olive mill effluents," Process Biochemistry 50(11), 1893-1903. DOI:

10.1016/j.procbio.2015.07.008 
Hashimoto, AG, Chen, YR, and Varel, VH. (1981). "Theoretical aspects of methane production: State of the art," Livestock Wastes: A Renewable Resource, Livestock Wastes: A Renewable Resource, Proceedings of International Symposium on Livestock Wastes, pp. 86-91.

IOC. (2016). World Table Olive Figures, International Olive Council, 1.

Krishnan, S., Singh, L., Sakinah, M., Thakur, S., Wahid, Z. A., and Alkasrawi, M. (2016). "Process enhancement of hydrogen and methane production from palm oil mill effluent using two-stage thermophilic and mesophilic fermentation," International Journal of Hydrogen Energy, 41(30), 12888-12898. DOI: 10.1016/j.ijhydene.2016.05.037

Lorenz, H., Fischer, P., Schumacher, B., and Adler, P. (2013). "Current EU-27 technical potential of organic waste streams for biogas and energy production," Waste Management 33(11), 2434-2448. DOI: 10.1016/j.wasman.2013.06.018

Lukehurst, C., Frost, P., and Seadi, T. (2010). Utilization of Digestate from Biogas Plants as a Biofertilizer, task 37, IEA Bioenergy, 24.

Macias-Corral, M., Samani, Z., Hanson, A., Smith, G., Funk, P., Yu, H., and Longworth, J. (2008). "Anaerobic digestion of municipal solid waste and agricultural waste and the effect of co-digestion with dairy cow manure," Bioresource Technology 99(17), 8288-8293. DOI: 10.1016/j.biortech.2008.03.057

Marques, I. P. (2001). "Anaerobic digestion treatment of olive mill wastewater for effluent re-use in irrigation," Desalination, 137(1), 233-239. DOI: 10.1016/S00119164(01)00224-7

MEMR. (2015). Ministry of Energy and Mineral Resources Annual Reports, annual report, Ministry of Energy and Mineral Resources, Jordan, 72.

Nielfa, A., Cano, R., and Fdz-Polanco, M. (2015). "Theoretical methane production generated by the co-digestion of organic fraction municipal solid waste and biological sludge," Biotechnology Reports, 5, 14-21. DOI: 10.1016/j.btre.2014.10.005

Rajagopal, R., Massé, D. I., and Singh, G. (2013). "A critical review on inhibition of anaerobic digestion process by excess ammonia," Bioresource Technology 143, 632641. DOI: 10.1016/j.biortech.2013.06.030

Sárvári Horváth, I., Tabatabaei, M., Karimi, K., and Kumar, R. (2016). "Recent updates on biogas production - A review," Biofuel Research Journal, 3(2), 394-402. DOI: 10.18331/BRJ2016.3.2.4

Sophie, B. (2008). "The state of the promotion of biogas from waste water plant in France and Europe."

Tarvin, D., and Buswell, A. M. (1934). "The methane fermentation of organic acids and carbohydrates1, 2," Journal of the American Chemical Society, 56(8), 1751-1755.

Tekin, A. R., and Dalgıç, A. C. (2000). "Biogas production from olive pomace," Resources, Conservation and Recycling 30(4), 301-313.

VDI 4630. (2006). "Fermentation of organic materials - Characterization of the substrate, sampling, collection of material data, fermentation tests," in: VDI Handbuch Energietechnik, Beuth Verlag GmbH, Berlin, pp. 44-59.

Weiland, P. (2003). "Production and energetic use of biogas from energy crops and wastes in Germany," Applied Biochemistry and Biotechnology 109(1), 263-274. DOI: 10.1385/ABAB: 109:1-3:263

Weiland, P. (2010). "Biogas production: Current state and perspectives," Applied Microbiology and Biotechnology 85(4), 849-860. DOI: 10.1007/s00253-009-2246-7 
Wu, X., Hui, K. N., Hui, K. S., Lee, S. K., Zhou, W., Chen, R., Hwang, D. H., Cho, Y. R., and Son, Y. G. (2012). "Adsorption of Basic Yellow 87 from aqueous solution onto two different mesoporous adsorbents," Chemical Engineering Journal 180, 9198. DOI: 10.1016/j.cej.2011.11.009

Wu, X., Yao, W., Zhu, J., and Miller, C. (2010). "Biogas and $\mathrm{CH}_{4}$ productivity by codigesting swine manure with three crop residues as an external carbon source," Bioresource Technology 101(11), 4042-4047. DOI: 10.1016/j.biortech.2010.01.052

Yadvika, Santosh, Sreekrishnan, T. R., Kohli, S., and Rana, V. (2004). "Enhancement of biogas production from solid substrates using different techniques-A review," Bioresource Technology 95(1), 1-10. DOI: 10.1016/j.biortech.2004.02.010

Yuan, H., and Zhu, N. (2016). "Progress in inhibition mechanisms and process control of intermediates and by-products in sewage sludge anaerobic digestion," Renewable and Sustainable Energy Reviews 58, 429-438. DOI: 10.1016/j.rser.2015.12.261

Article submitted: July 12, 2017; Peer review completed: October 8, 2017; Revised version received: October 19, 2017; Accepted: October 25, 2017; Published: October 30, 2017.

DOI: 10.15376/biores.12.4.9383-9395 